Revista Destaques Acadêmicos, Lajeado, v. 9, n. 2, 2017. ISSN 2176-3070 DOI: http://dx.doi.org/10.22410/issn.2176-3070.v9i2a2017.1298 www.univates.br/revistas

\title{
OS SUJEITOS NO PROCESSO PENAL: DIREITOS, DEVERES E FUNÇÕES
}

\author{
Cláudia Daniela Behrens ${ }^{1}$
}

Resumo: A sociedade, sendo um agrupamento de pessoas, que vivem de maneira organizada, em determinado lapso temporal e espacial, demanda a existência de normas materiais tendentes à punição daqueles que, por ventura, violem a paz social. Outrossim, uma vez transgredida a lei penal, tem-se o desencadeamento de atos interdependentes, no meio processual, propensos à solução do litígio, ora verificado. Ademais, tais atos processuais vêm regulados pelo Código de Processo Penal, o qual atribui a determinadas pessoas, chamadas de sujeitos processuais, diversos direitos e obrigações a serem perpetrados durante a persecução penal até a resolução da lide, com a condenação ou absolvição do acusado pelos atos praticados.

Palavras-chave: Paz social. Crime. Persecução penal. Sujeitos processuais. Justiça.

\section{INTRODUÇÃO}

A sociedade, com seu rápido avanço e evolução, impõe ao Estado a edição de normas que visem regular as relações sociais, de modo a garantir a paz social, além de punir aqueles que desrespeitam a ordem jurídica, cometendo atos ilícitos e gerando danos ao meio coletivo. O Estado Democrático de Direito, autônomo e soberano, por força constitucional, é formado pela divisão tripartite dos poderes - Legislativo, Executivo e Judiciário.

Neste diapasão, diante da ocorrência de um fato delituoso, este será sucedido por uma investigação preliminar, a ser realizada pela autoridade policial. Esta, por seu turno, ao concluir o procedimento investigatório, o encaminhará ao órgão público acusatório, para o fim de promover a respectiva ação penal, colimando pela concretização da pretensão punitiva estatal.

1 Acadêmica do Curso de Direito, Univates. Bolsista no Tribunal de Justiça do Rio Grande do Sul. 
Tal sequência, outrossim, que configura a persecução penal, prosseguirá no Poder Judiciário, o qual solucionará a lide ${ }^{2}$. Inobstante, ao ser provocado com a dedução da pretensão punitiva, o órgão jurisdicional formará sua convicção, através dos elementos probatórios, para, então, decidir e aplicar a lei ao caso concreto.

Ainda, neste teor, sendo o Estado detentor da prerrogativa de punir aquele que violar os interesses jurídicos da sociedade, somente a ele é imposta a capacidade de decidir os conflitos de interesses, sendo vedada a autotutela, que, há alguns séculos, predominava como forma de pacificação social.

A jurisdição, função desempenhada pelo Poder Judiciário, na figura do Estado-Juiz, compreende os atos do magistrado de conduzir o processo crime até a sua resolução, de modo que exerça o poder jurisdicional e o múnus público que a lei lhe confere. Logo, ao Estado é atribuído o monopólio da persecução penal, bem como do jus puniendi ${ }^{3}$.

A persecução penal gize-se, ademais, compreende uma sequência de atos realizados por diversos sujeitos, os quais são personagens jurídicos que exercem relevantes funções no curso da demanda. Por conseguinte, os atos processuais praticados por estes sujeitos são necessários à correta e adequada condução do processo criminal, que é o instrumento de concretização do direito material.

Em vista destas considerações, objetiva-se, nesta pesquisa, examinar e identificar os sujeitos no processo penal, bem como as suas funções, direitos e incumbências ao regular prosseguimento da demanda até a sua consecutiva solução. Por ora, infere-se que o processo requer seja impulsionado tanto pelas partes, quanto por seus representantes ou assistentes, mediante o direcionamento do Juiz, com o auxílio dos serventuários da justiça. Portanto, a atuação dos sujeitos no curso do processo penal é elemento necessário à sua existência.

Referente à metodologia utilizada neste trabalho, trata-se de pesquisa exploratória que busca aprimorar e desenvolver ideias, de forma a contribuir para uma melhor e ampla compreensão do tema abordado. Ademais, é uma pesquisa bibliográfica, visto que é baseada em livros, doutrinas e materiais elaborados e publicados por profissionais que atuaram e continuam atuando no Poder Judiciário, Ministério Público, além da Advocacia, sendo alusivos ao assunto em questão.

Colimando alcançar os objetivos propostos, esta pesquisa apresenta as seguintes subdivisões: Do Juiz (funções, poderes, prerrogativas e vedações,

2 Conflito de interesses formado por uma pretensão resistida, em que confere-se ao Estado o poder de exercer sua pretensão punitiva em face do réu, o qual possui o direito de liberdade.

3 Dever de punir do Estado. 
impedimentos e suspeição); Do Ministério Público (funções princípios prerrogativas e garantias vedações impedimentos e suspeição); Do acusado (capacidade processual, direitos e garantias, condução coercitiva); Do Defensor (Defensor Público, Defensor constituído, Defensor dativo, autodefesa); Da vítima; Da assistência à acusação (da admissão, poderes); Dos funcionários da justiça (Do Perito, Do Intérprete, Dos impedimentos).

\section{DO JUIZ}

\subsection{Funções}

No processo crime pressupõe-se a existência de um conflito de interesses, que é a pretensão resistida, formada pelo jus libertatis ${ }^{4}$ e o jus puniendi $i^{5}$. Nesse contexto, o Juiz, além de substituir a vontade das partes, está incumbido de aplicar o direito material ao caso concreto, de modo a solucionar a lide, e, por consequência, restabelecer a paz social.

Nesta linha, tem-se que o magistrado é sujeito na relação processual, e não parte, razão pela qual atua em nome do Estado. Assim sendo, o julgador deve possuir capacidade e investidura no cargo, que se dá através de concurso público.

Além de atuar com total imparcialidade durante todo o curso do processo, o magistrado não pode estar impedido ou suspeito, tampouco apresentar causa de incompatibilidade que o impossibilite de dar seguimento à demanda. Portanto, a lei confere ao julgador determinados poderes, a fim de que possa garantir a efetividade da função jurisdicional.

\subsection{Poderes}

Os poderes conferidos ao magistrado se classificam em: a) poderes de polícia ou administrativos: que visam garantir a disciplina e o decoro durante o curso do processo, evitando-se, assim, atos e manifestações das partes e terceiros que possam perturbar o prosseguimento da demanda; e, b) poderes jurisdicionais: que são alusivos à condução do processo; como exemplos, temse a tomada de decisões, além da colheita de provas, o comando sentencial, entre outros.

De acordo com Avena (2014, texto digital), os poderes jurisdicionais, por sua vez, subdividem-se em 1) poderes meios, que abrangem os atos ordinatórios (impulsionam o processo até a prolação de sentença) e atos instrutórios (formam a convicção do julgador, a fim de que este decida a

4 Direito de liberdade do réu.

5 Dever de punir do Estado. 
partir dos elementos colhidos na fase instrutória); e, 2) poderes fins, que compreendem os atos executórios (atos tendentes à execução das decisões judiciais) e atos decisórios (pronunciamentos do magistrado durante a fase de conhecimento do processo, trazendo sucumbências às partes).

\subsection{Prerrogativas e vedações}

Conforme assevera Avena (2014, texto digital), são conferidas garantias ao julgador, com fundamento constitucional, a fim de viabilizar e assegurar o pleno exercício da atividade jurisdicional, de modo imparcial. Tais prerrogativas, outrossim, vêm previstas no art. 95, da Constituição Federal (CF).

Nesta linha, segundo o autor, as prerrogativas são a vitaliciedade, a inamovibilidade e a irredutibilidade de subsídio. Já, no que tange às garantias, tem-se o ingresso na carreira mediante concurso público de provas e título, e, ainda, a promoção para entrância superior, de acordo com parâmetros de antiguidade e merecimento.

As vedações impostas aos Juízes, de outra banda, consistem em limitações estabelecidas àqueles, de modo a preservar a liberdade, a imparcialidade, bem como impedir que o magistrado exerça qualquer outra atividade que venha a comprometer a dedicação necessária à atividade jurisdicional. Neste teor, Avena (2014, texto digital), explana que as vedações estão previstas, mormente, no art. 95, § único, CF.

Assim, as vedações compreendem: o exercício de outro cargo/função (exceto de magistério); o recebimento de custas/participação em outro processo; a dedicação em atividades político-partidária; além do recebimento de contribuições/auxílios (seja de pessoa física, entidades públicas/privadas), excetuando os casos previstos em lei; e, ainda, o exercício da advocacia no juízo do qual se afastou, antes do decurso de três anos (chamado período de quarentena) deste afastamento, seja por aposentadoria ou exoneração.

\subsection{Impedimentos e suspeição}

Segundo expõe Avena (2014, texto digital), as causas de impedimento geram a incapacidade objetiva do Juiz, na medida em que são alusivas à sua relação com o objeto da lide. O Código de Processo Penal (CPP), outrossim, prevê as hipóteses de impedimento no art. 252, in verbis:

Art. 252. O juiz não poderá exercer jurisdição no processo em que: I - tiver funcionado seu cônjuge ou parente, consanguíneo ou afim, em linha reta ou colateral até o terceiro grau, inclusive, como defensor ou advogado, órgão do Ministério Público, autoridade policial, auxiliar da justiça ou perito; 
II - ele próprio houver desempenhado qualquer dessas funções ou servido como testemunha;

III - tiver funcionado como juiz de outra instância, pronunciando-se, de fato ou de direito, sobre a questão;

IV - ele próprio ou seu cônjuge ou parente, consanguíneo ou afim em linha reta ou colateral até o terceiro grau, inclusive, for parte ou diretamente interessado no feito.

Oportuno mencionar que tais hipóteses são taxativas, não sendo admitida a analogia, tampouco a interpretação extensiva destas circunstâncias. Ainda, repisa-se que tais causas deverão ser reconhecidas de ofício pelo julgador ou pelas partes, através de exceção de suspeição, conforme previsão do art. 112, do CPP.

A suspeição, por outro lado, diz respeito à incapacidade subjetiva do Juiz, segundo elucida Avena (2014, texto digital), eis que vincula o magistrado a uma das partes. As hipóteses de suspeição estão elencadas no art. 254, do $\mathrm{CPP}$, in verbis:

Art. 254. O juiz dar-se-á por suspeito, e, se não o fizer, poderá ser recusado por qualquer das partes:

I - se for amigo íntimo ou inimigo capital de qualquer deles;

II - se ele, seu cônjuge, ascendente ou descendente, estiver respondendo a processo por fato análogo, sobre cujo caráter criminoso haja controvérsia;

III - se ele, seu cônjuge, ou parente, consanguíneo, ou afim, até o terceiro grau, inclusive, sustentar demanda ou responder a processo que tenha de ser julgado por qualquer das partes;

IV - se tiver aconselhado qualquer das partes;

$\mathrm{V}$ - se for credor ou devedor, tutor ou curador, de qualquer das partes;

VI - se for sócio, acionista ou administrador de sociedade interessada no processo.

De igual forma, as causas de suspeição poderão ser arguidas pelas partes, através de exceção, nos moldes do art. 96, do mesmo diploma legal, ou pelo magistrado, que se dará como suspeito na ação.

\section{DO MINISTÉRIO PÚBLICO}

A expressão Parquet, conforme explica Paes (2012, texto digital), possui origem francesa e significa assoalho, sendo normalmente utilizada como sinônimo de Ministério Público, visto que "na Idade Média os procuradores do rei ainda não dispunham das garantias dos magistrados e assim, diante de uma audiência, recebiam determinação expressa para se sentarem no assoalho das salas ao invés de acomodarem-se no estrado". 
De outra banda, ao Ministério Público é atribuída a função de defender a ordem jurídica, o regime democrático, além dos interesses sociais e individuais indisponíveis, sendo instituição permanente, essencial à função jurisdicional do Estado, conforme previsão do art. 127, da CF.

\subsection{Funções}

$\mathrm{Na}$ seara criminal, o agente ministerial representa o EstadoAdministração, consoante refere Avena (2014, texto digital), estando incumbido de buscar a concretização da pretensão punitiva, promovendo, privativamente, a ação penal pública; além de fiscalizar a instauração, desenvolvimento e execução do processo nos crimes de ação penal privada.

Desta forma, segundo o autor, o Ministério Público poderá exercer, cumulativamente, a função de custos legis ${ }^{6}$, além da propositura da ação penal. Inobstante, o Parquet, conforme acentua Nucci (2014, p. 496), ao receber o Inquérito Policial, presidido pela autoridade policial, poderá requerer diligências, bem como pedir a extinção de punibilidade ou arquivamento, além de oferecer a denúncia.

Ainda, consoante assinala Nucci (2014, p. 494), mostra-se inadequado afirmar que o membro do Ministério Público é parte imparcial, uma vez que aquele não está obrigado a demandar a condenação daquele que julgar inocente, tampouco de propor a ação penal quando inexistirem provas suficientes. Desta feita, o Ministério Público é parte parcial, considerando que pode pedir a absolvição do réu, além de outros benefícios que, eventualmente, julgar pertinentes ao caso concreto.

Ademais, a organização do Ministério Público é composta por: a) Ministério Público da União (chefia - Procurador-Geral da República), que abrange o Ministério Público Federal, o Ministério Público do Trabalho, o Ministério Público Militar e o Ministério Público do Distrito Federal; e, b) Ministério Público dos Estados (chefia - Procurador-Geral de Justiça), segundo previsão do art. 128, da CF.

\subsection{Princípios}

Os princípios que regem o Ministério Público estão elencados no art. 127, parágrafos $1 .^{\circ}$ e 2. ${ }^{\circ}$, da CF. São eles: unidade (membros pertencem à uma mesma instituição, que possui a chefia de um Procurador-Geral); indivisibilidade (a atuação do órgão ministerial se manifesta e é considerada como atuação da instituição como um todo, e não do membro, isolado); independência funcional (o Ministério Público possui independência no exercício de suas funções, não

6 Guardião da lei, o qual fiscaliza a sua correta aplicação. 
é subordinando aos Poderes Estatais - Legislativo, Executivo, Judiciário, é vinculado, apenas, à Constituição Federal e Leis Estaduais).

O Ministério Público, ainda, é dotado de autonomia funcional, administrativa e financeira, segundo dicção do art. 127, parágrafos $2 .^{\circ}$ e $3 .^{\circ}$, da $\mathrm{CF}$, que são atinentes à capacidade organizacional, de gerenciamento de questões internas administrativas, além da elaboração de proposta orçamentária, de acordo com Avena (2014, texto digital).

\subsection{Prerrogativas e Garantias}

A Lei 8.625/93, em seu art. 38, capitula as prerrogativas irrogadas ao órgão parquetário, quais sejam: vitaliciedade, inamovibilidade e irredutibilidade de subsídio. Assim, a par destes critérios, verifica-se que há simetria entre as prerrogativas conferidas ao magistrado, de modo que se garanta, também, aos membros do Ministério Público a isenção absoluta no exercício de suas funções e atribuições, seja atuando como custos legis, seja sendo o autor da ação penal pública, conforme explica Avena (2014, texto digital).

\subsection{Vedações}

As limitações ao agente ministerial vêm elencadas no art. $128, \S 5 .^{\circ}$, II, da CF:

a) receber, a qualquer título e sob qualquer pretexto, honorários, percentagens ou custas processuais;

b) exercer a advocacia;

c) participar de sociedade comercial, na forma da lei;

d) exercer, ainda que em disponibilidade, qualquer outra função pública, salvo uma de magistério;

e) exercer atividade político-partidária;

f) receber, a qualquer título ou pretexto, auxílios ou contribuições de pessoas físicas, entidades públicas ou privadas, ressalvadas as exceções previstas em lei.

Também, o parágrafo $6 .^{\circ}$, deste mesmo artigo, dispõe que é vedado ao membro do Ministério Público exercer a advocacia no juízo ou tribunal do qual se afastou, antes de decorridos três anos do afastamento do cargo por aposentadoria ou exoneração.

\subsection{Impedimentos e Suspeição}

O art. 258, do CPP, impõe tratamento análogo entre o órgão ministerial e o Juiz, prevendo como causas de impedimento/suspeição as seguintes hipóteses: 
Art. 258. Os órgãos do Ministério Público não funcionarão nos processos em que o juiz ou qualquer das partes for seu cônjuge, ou parente, consanguíneo ou afim, em linha reta ou colateral, até o terceiro grau, inclusive, e a eles se estendem, no que Ihes for aplicável, as prescrições relativas à suspeição e aos impedimentos dos juízes.

Ademais, segundo Avena (2014, texto digital), o agente ministerial que requereu o arquivamento do inquérito policial ou peças de informação, referentes à ação penal promovida em razão de rejeição do pedido de arquivamento, também estará impedido de atuar no processo.

Nucci (2104, p. 496) dita que o Promotor de Justiça que participou da investigação policial não se torna impedido, tampouco suspeito, ao oferecimento da denúncia, remetendo à Súmula 234, do STJ: “A participação do membro do Ministério Público na fase investigatória criminal não acarreta o seu impedimento ou suspeição para o oferecimento da denúncia".

\section{DO ACUSADO}

Conforme argumenta Nucci (2014, p. 496), o acusado é sujeito passivo da relação processual. Logo, durante a investigação não há que se falar em acusado ou réu, e sim em indiciado ou suspeito, de acordo com Lopes Jr. (2013, p. 738). Este autor, ademais, salienta que o art. 5. ${ }^{\circ}, \mathrm{LV}$, da CF, traz o tratamento "acusado" em sentido amplo, para alcançar o inquérito policial, e, também, o processo criminal.

Avena (2014, texto digital) complementa dizendo que o acusado é aquele "a quem é imputada a prática de uma infração penal, e em face de quem se busca que seja realizada a pretensão punitiva do Estado". Ainda, de acordo com o procedimento, a concepção "acusado" poderá mudar, segundo explica Torres (2015, texto digital).

Nesta linha, pormenorizando-se, tem-se o inquérito policial, na fase pré-processual, em que é nominado investigado/averiguado, ou, caso já haja indiciamento, chamar-se-á de indiciado o agente criminoso, que é o autor do delito. Com o advento da denúncia, passa a chamar-se de denunciado. Sendo aquela recebida pelo julgador, passará, então, a chamar-se de acusado ou réu. Por fim, depois de transitada em julgado a sentença penal condenatória, chamarse á de condenado, consoante disposições de Torres (2015, texto digital).

\subsection{Capacidade processual}

O acusado, para figurar no polo passivo do processo crime, deverá possuir legitimidade ou capacidade para tanto. Neste pretexto, de acordo com Torres (2015, texto digital) o acusado "é o suposto autor da infração penal, 
é aquele a quem se imputa a prática de uma conduta criminosa. É sujeito passivo da relação processual e sujeito ativo da relação material".

Registre-se, também, que, em face do princípio da intranscendência, a condição de acusado é personalíssima, eis que "somente recai no autor da infração" (TORRES, 2015, texto digital), não se transmitindo aos seus herdeiros. É necessário, ademais, que haja uma individualização do acusado no processo penal, trazendo-se as suas devidas qualificações, evitando-se, assim, eventuais homonímias no polo passivo da demanda.

Avena (2014, texto digital) elenca as seguintes hipóteses em que não há legitimidade para figurar como acusado no processo criminal:

a) Os entes que não possuem capacidade para serem sujeitos de direitos e obrigações, (...), pessoas já falecidas.

b) Menores de 18 anos de idade, por faltar-lhes o requisito da legitimidade passiva ad causam. (...)

c) Pessoas que gozem de imunidade diplomática, o que abrange os chefes de Estado e os representantes de governos estrangeiros, que estão excluídos da jurisdição criminal dos países em que exercerem suas funções. (...)

d) Pessoas que estiverem ao abrigo de imunidade parlamentar material, como a estabelecida constitucionalmente aos deputados e senadores, que são invioláveis, civil e penalmente, em quaisquer manifestações proferidas no exercício ou desempenho de suas funções.

As pessoas jurídicas, outrossim, podem vir a ocupar o polo passivo do processo criminal, desde que se tratem de crimes contra a ordem econômica e financeira, além da economia popular e crimes ambientais, considerando o disposto no art. 173 , parágrafo $5 .^{\circ}$, e 225 , parágrafo $3 .^{\circ}$, da CF.

Em se tratando de portador de doença mental, à época dos fatos, Avena (2014, texto digital) refere que não há impedimento para que o agente integre o polo passivo, ainda que se trate de patologia que gere a inimputabilidade ou semi-imputabilidade do acusado. Assim, nestes casos, poderá ser instaurado o incidente de insanidade mental, com fulcro no art. 151, do CPP, ou, ainda, a aplicação de medida de segurança, de acordo com os artigos 97 e 98, do Código Penal (CP), se necessário.

\subsection{Direitos e Garantias}

Conforme expõe Avena (2014, texto digital), os direitos do acusado estão previstos, na sua grande maioria, na Constituição Federal, encontrandose, também, no CPP. Citam-se:

- Respeito à integridade física e moral (art. 5. $\left.{ }^{\circ}, \mathrm{XLIX}, \mathrm{CF}\right)$; 
- Ser processado e sentenciado pela autoridade competente (art. 5. ${ }^{\circ}$, LIII, CF);

- Devido processo legal (art. 5. $\left.{ }^{\circ}, \mathrm{LIV}, \mathrm{CF}\right)$;

- Contraditório e ampla defesa (art. 5. ${ }^{\circ}, \mathrm{LV}, \mathrm{CF}$ );

- Presunção de inocência até o trânsito em julgado da condenação (art. 5. ${ }^{\circ}, \mathrm{LVII}, \mathrm{CF}$ );

- Não ser submetido à identificação criminal, excetuando as hipóteses legais (art. 5. ${ }^{\circ}$, LVIII, CF e Lei 10.054/2000);

- Processo e julgamento público, salvo se necessário o sigilo a fim de preservar a intimidade ou envolver interesses sociais (arts. 5. ${ }^{\circ}, \mathrm{LX}$, e 93, IX, CF);

- Não ser preso, exceto se em flagrante delito ou por ordem escrita emanada da autoridade judiciária competente, salvo demais casos estabelecidos pela lei (art. 5. ${ }^{\circ}$, LXI, CF e art. 282,CPP);

- Informação de seus direitos quando for preso (de permanecer calado, assistência à família e advogado) (art. 5. ${ }^{\circ}$, LXIII, CF e art. $\left.306, \S 2 .^{\circ}, \mathrm{CPP}\right)$;

- Não ser preso ou ser mantido na prisão se a lei possibilitar a liberdade provisória, com ou sem fiança (art. 5. ${ }^{\circ}, \mathrm{LXVI}, \mathrm{CF}$ );

- Ciência quanto à identidade dos responsáveis pela sua prisão ou interrogatório policial, quando for preso (art. 5. ${ }^{\circ}$, LXIV, CF e arts. 288 e 291, CPP);

- Inadmissibilidade de provas obtidas por meios ilícitos em seu desfavor (art. 5. ${ }^{\circ}, \mathrm{LVI}, \mathrm{CF}$ );

- Assistência jurídica integral e gratuita, se não dispuser de recursos financeiros à constituição de advogado (art. 5. ${ }^{\circ}$, LXXIV, CF e Lei 1.060/1950);

- Indenização por erro judiciário ou pelo tempo que permanecer preso indevidamente (art. 5. ${ }^{\circ}, \mathrm{LXXV}, \mathrm{CF}$ );

- Razoável duração do processo e meios céleres à sua tramitação (art. 5. ${ }^{\circ}$, LXXVIII, CF);

- Entrevista prévia e reservada com advogado, seja este constituído ou nomeado, antes do interrogatório em juízo (art. 185, § 2. ${ }^{\circ}, \mathrm{CPP}$ );

- Que o seu silêncio não seja interpretado como confissão ficta ou ser utilizado pelo juiz em seu desfavor (art. 186, parágrafo único, CPP);

- Possibilitar tradutor ou intérprete, se vier a desconhecer o idioma nacional ou se não puder se comunicar por deficiência auditiva ou vocal (arts. 192 e 193, CPP);

- Defesa técnica fundamentada, se for assistido por defensor dativo ou público (art. 261, parágrafo único, CPP).

\subsection{Condução Coercitiva}

Lopes Jr. (2013, p. 767) critica este instituto, explanando que "é preciso compreender que o estar presente no processo é um direito do acusado; nunca um dever". Logo, este autor afirma que o acusado não é objeto do processo, não 
sendo obrigado à submissão de quaisquer atos probatórios, tampouco a sua presença física, visto que é sua opção apresentar-se nos autos.

Expõe, ademais, que o acusado possui o direito ao silêncio, estando "logicamente autorizado a não comparecer", bem como que seu eventual não comparecimento "não conduzirá a nenhum tipo de punição processual, exceto o fato de o processo continuar seu curso em sua ausência" (LOPES JR., 2013, p. 767). Por outro lado, mesmo criticando, o autor mensura que a condução coercitiva, diante do não comparecimento do réu, somente deve ser cabível "para prestar declarações na polícia ou em juízo", sendo concebida, apenas, "quando precedida de ordem judicial devidamente fundamentada" (LOPES JR. 2013, p. 767).

\section{DO DEFENSOR}

A CF, em seu art. 133, preceitua que "o advogado é indispensável à administração da justiça". Logo, em face da indisponibilidade do direito de defesa do acusado, bem como frente à sua necessidade de ser assessorado por profissional com capacidade técnica, a fim de efetivar aquele direito, realizando a sua defesa; é obrigatória a presença de defensor, de acordo com Avena (texto digital, 2014).

De outra banda, o defensor, ao ser constituído, deverá juntar aos autos do processo criminal o respectivo instrumento de mandato, sob pena de tornaremse nulos, ou, ainda, inexistentes os atos por ele praticados. Em determinadas situações, ressalte-se que, além da procuração genérica, a lei poderá exigir que o advogado possua poderes especiais em relação ao réu, o que deverá constar no mandato. Neste contexto, Avena (2014, texto digital) cita como exemplos: a aceitação do perdão do ofendido (art. 59 do CPP), a arguição de exceção de suspeição do juiz (art. 98 do CPP), além da arguição da falsidade documental (art. 146 do CPP).

No decorrer do processo, o defensor, além de estar presente fisicamente, deverá prestar a defesa de forma eficiente, trazendo aos autos argumentos capazes de formar a convicção do magistrado em favor do acusado, sob pena de ser nomeado outro defensor para defender o réu, consoante expõe Avena (2014, texto digital). Nesse sentido, o art. 396-A, do CPP, dispõe que “Na resposta, o acusado poderá arguir preliminares e alegar tudo o que interesse à sua defesa, oferecer documentos e justificações, especificar as provas pretendidas e arrolar testemunhas $(. . .)^{\prime \prime}$.

\subsection{Defensor Público}

Brandão (2011, texto digital) explica que a assistência jurídica, que é direito constitucional garantido ao acusado, possui conotação ampla, na medida em que "abrange a assistência judiciária em sentido estrito, como também a prestação de informação e consultoria jurídicas". Deste modo, a 
assistência judiciária pode ser oferecida tanto por órgãos estatais, quanto por entidades não-estatais ou advogados que desempenham tal função junto ao Poder Público, segundo enuncia Brandão (2011, texto digital).

O Defensor Público, ademais, atuante na Defensoria Pública dos Estados, da União ou Distrito Federal, exerce "um serviço público prestado com o objetivo de defender em juízo a pessoa assistida" (BRANDÃO, 2011, texto digital). Ademais, o art. 134, da CF, preceitua que a Defensoria Pública é incumbida de prestar o serviço da assistência jurídica, posto que é instituição essencial à função jurisdicional do Estado.

Portanto, o papel do Defensor Público é defender e orientar juridicamente os necessitados, em todos os graus de jurisdição, assegurando àqueles que apresentam hipossuficiência financeira a assistência jurídica, integral e gratuita. Em vista disso, a CF, ao prever tais direitos ao acusado, colimou por garantir "a igualdade jurídica a um número indeterminado de indivíduos, para que eles adquiram direitos e contraiam obrigações, sem perder sua dignidade como pessoa humana e também sua cidadania" (BRANDÃO, 2011, texto digital).

Souza Jr. (2006, texto digital) assinala, ainda, que:

[A Defensoria Pública] é uma instituição de caráter assistencial às pessoas carentes, gratuitamente, também tem essencial papel para o desenvolvimento da função jurisdicional do Estado. Ou seja, este órgão foi fundado com finalidade de prestar assistência aos carentes financeiramente, onde lhes são garantidos tanto o direito de ação consagrado na Constituição Federal, como o direito de defesa.

Destarte, o Poder Público deve assegurar ao acusado o acesso à justiça, de maneira igualitária, integral, e gratuita, por ser garantia constitucional. Assim, é "reservado o direito ao acusado de se ver defendido por um "advogado popular" (SOUZA JR., 2006, texto digital), que, neste caso, é o papel exercido pelo Defensor Público.

\subsection{Defensor constituído}

O Defensor constituído ou nomeado é aquele que o réu escolhe e contrata para realizar a sua defesa no curso do processo criminal, sem haver a necessidade de nomeação pelo Juiz. Logo, dispondo de recursos financeiros e não se enquadrando na classe de necessitados ou com hipossuficiência de recursos financeiros, o réu elegerá um advogado, contratando-o, para que exerça a sua defesa no curso do processo, representando-o nos autos.

Importa salientar, de acordo com Nucci (2014, p. 501), que em eventual nomeação de defensor, realizada pelo Juiz, o acusado poderá, a qualquer tempo, nomear e contratar outro advogado de sua confiança, bem como exercer sua própria defesa, se for advogado, nos moldes do art. 263, do CPP. 


\subsection{Defensor dativo}

Na seção 5.1 explicitou-se acerca do ofício do Defensor Público, que atua pela Defensoria Pública. Neste sentido, registra-se, desde já, que o Defensor dativo não pertence àquele órgão estatal, embora exerça o papel do Defensor Público, auxiliando o acusado, por indicação da Justiça. Logo, o Defensor dativo não possui vínculo empregatício com o Estado, não possuindo, ademais, direitos como o Defensor Público irroga.

Gize-se, outrossim, que seus honorários são pagos pelo ente estatal, quando for nomeado a realizar a curadoria especial daquele que necessitar, consoante infere Rodas (2015, texto digital). Neste teor, se o réu for pobre, não dispondo de recursos financeiros para contratação de advogado, aquele não está obrigado a arcar com os honorários do Defensor dativo, que serão arbitrados pelo Juiz e desembolsados pelo ente estatal.

Destaca-se ainda, nesta linha, que, eventualmente, os "honorários serão pagos ao final do processo pela parte vencida ou, se esta gozar dos benefícios da Justiça gratuita, pelo Estado" (RODAS, 2015, texto digital).

\subsection{Autodefesa}

Para que a autodefesa seja desempenhada pelo acusado, é necessário que este esteja presente, pessoalmente, durante a realização de audiência de instrução e julgamento, ou, ainda, de eventuais oitivas de testemunhas que ocorram fora desta solenidade, conforme explana Pupo (2011, texto digital).

Ainda, segundo assevera este autor, “a autodefesa pressupõe a participação - pessoal - do acusado nos atos processuais (direito de presença), sendo que aquela meramente virtual não é suficiente" (PUPO, 2011, texto digital).

Vale (2014, texto digital) argumenta que a autodefesa "é realizada pelo próprio réu em pessoa, sem necessitar da mediação de um advogado", além de que "não implica a habilitação técnico-jurídica", considerando que o acusado pode realizá-la sem possuir habilitação como advogado. Portanto, a autodefesa do réu não se confunde com a defesa técnica; intermediada por defensor inscrito regularmente na $O A B$, sendo habilitado a exercer a advocacia. Possibilita-se, assim, ao acusado se defender pessoalmente das alegações lhe imputadas, consoante preceitua Vale (2014, texto digital).

\section{DA VÍTIMA}

A vítima é a pessoa que sofreu diretamente os danos físicos e psicológicos oriundos do fato delituoso. Assim, ao participar do processo criminal exerce papel coadjuvante à diminuição da insatisfação da sociedade e do próprio ofendido pela ocorrência do ilícito que violou a ordem jurídica. Desta forma, viabiliza a composição nos crimes menos graves, como nos casos da Lei 
9.099/95 (Juizados Especiais) através de acordos estabelecidos com o autor do fato, além de atuar como assistente à acusação nos demais crimes.

De acordo com Petek (2010, texto digital), em atuando como assistente do Ministério Público (ver seção 2.7), a vítima poderá intervir no processo, corroborando a função acusatória. Descreve, o autor, as seguintes intervenções que a vítima poderá exercer no curso do processo atuando como assistente à acusação:

(...) Compete-lhes (i) intervir no inquérito e na instrução, oferecendo provas e requerendo diligências que se afigurem necessárias; (ii) deduzir acusação independente da acusação do Ministério Público e, no caso de procedimento dependente de acusação particular, ainda que aquele não a deduza; (iii) interpor recurso das decisões que os afetem, mesmo que o Ministério Público não o tenha feito. Ainda, poderá o assistente requerer a intervenção do júri para julgamento dos feitos de sua competência (art. 13), requerer ao Tribunal a cessação da conexão (art. 30) e arguir exceção de incompetência (art. 32).

(...)

Ainda se permite ao assistente requerer a "aceleração de processo atrasado" (art. 108); requerer perícia e designar assistente técnico (arts. 1532 1.534); requerer revisão e confirmação de sentença penal estrangeira (art. 236); e prestar declarações em juízo (art. 346) (...)

Petek (2010, texto digital) refere, também, que a atividade da vítima, juntamente do Ministério Público, estabelece um "litisconsórcio criminal", visto que é parte contingente, pois apresenta-se prescindível ao início e desenvolvimento da ação penal. Ademais, alude, ainda, o autor, que a vítima dispõe de poderes independentes para agir no curso do processo, razão pela qual, reforça que "funciona como litisconsorte do órgão acusatório público, seja para obter a garantia do justo ressarcimento, para a correta aplicação da lei penal, seja, ainda, como forma de controle externo da atividade do Ministério Público" (PETEK, 2010, texto digital).

Convém explicitar que o assistente de acusação é a vítima que intervém na ação penal pública, seja esta incondicionada ou condicionada à representação, no intuito de buscar a reparação do interesse jurídico violado, além de colimar auxiliar a instituição ministerial na adequada aplicação da lei penal ao acusado. Logo, é o próprio ofendido, ou seu representante legal, ou, ainda, aquelas pessoas elencadas no art. 31, do CPP, que auxiliarão o órgão parquetário na função acusatória, consoante acentua Petek (2010, texto digital).

Frente a estas considerações, este autor positiva que a vítima (assistente da acusação) exerce função de natureza específica, consistente na reparação civil dos danos; além da função de ampla natureza, que compreende o auxílio prestado, através de sua intervenção no processo, à correta e adequada 
aplicação da norma penal. Conclui-se esta seção citando-se o entendimento de Fernando Tourinho Filho apud Petek (2010, texto digital):

Entendemos que a razão de se permitir a ingerência do ofendido em todos os termos da ação penal pública, ao lado do Ministério Público, repousa na influência decisiva que a sentença da sede penal exerce na sede civil. (...) Conclui-se, pois, que a função do assistente não é a de auxiliar a Acusação, mas a de procurar defender seu interesse na indenização do dano ex delicto.

Portanto, a vítima, ao intervir no processo crime, na forma de assistente de acusação, exerce relevante papel na manutenção da tranquilidade social, posto que é cidadão de direitos, possuindo a faculdade de participar e intervir nos processos decorrentes de atos ilícitos que lhe causarem ofensa e agressão aos seus bens jurídicos. Nesse sentido, ainda de acordo com Petek (2010, texto digital), a vítima contribuirá à aplicação correta da lei penal, além de proporcionar a reparação dos danos causados pelo acusado, visando, acima de tudo, restabelecer a paz social.

\section{DA ASSISTÊNCIA À ACUSAÇÃO}

$\mathrm{O}$ art. 268, do CPP estabelece que "o ofendido ou seu representante legal, ou, na falta, qualquer das pessoas mencionadas no art. $31^{7 \prime \prime}$, poderá intervir na ação penal pública como assistente do Ministério Público/assistente de acusação. Diante deste pretexto, confere-se, segundo Avena (2014, texto digital), que não é o advogado que atua no processo de forma a auxiliar o Ministério Público na função acusatória, mas a própria vítima, que sofreu a lesão em seu bem jurídico.

Nucci (2014, p. 505) assinala, ademais, que a assistência à acusação é a posição ocupada pelo ofendido ao ingressar no feito, de forma a atuar no polo ativo, juntamente do Ministério Público. A vítima, destarte, mostra-se como sujeito e parte secundária na relação processual, não sendo obrigatória a sua intervenção.

Portanto, é a própria vítima, seus representantes ou as pessoas elencadas no art. 31, do CPP, que intervém na ação penal pública, corroborando o agente ministerial na acusação. Por outro lado, cita-se o art. 270, do mesmo diploma legal, que proíbe o corréu de intervir como assistente de acusação no mesmo processo.

7 Art. 31. No caso de morte do ofendido ou quando declarado ausente por decisão judicial, o direito de oferecer queixa ou prosseguir na ação passará ao cônjuge, ascendente, descendente ou irmão. 


\subsection{Da admissão}

Para a prática de atos processuais, o assistente, devidamente representado por advogado, deverá requerer ao Juiz que o declare habilitado a intervir na acusação. Sendo o respectivo requerimento acostado aos autos, o magistrado deverá, primeiramente, ouvir o agente ministerial, por força do art. 272, do CPP. Avena (2014, texto digital) enumera os aspectos a serem apreciados pelo julgador durante a análise e decisão do pedido de habilitação:

$1^{\circ} .^{\circ}$. Tratar-se o requerente de um dos legitimados previstos no art. 268 do CPP, documentando-se o vínculo de parentesco ou a representação legal no caso de ser a vítima incapaz, declarada ausente ou morta;

$2^{\circ}{ }^{\circ}$. Encontrar-se o requerente assistido por advogado munido de instrumento procuratório, salvo se ele próprio possuir essa capacitação profissional;

3. ${ }^{\circ}$ ). Não se tratar de corréu no mesmo processo (art. 270 do CPP).

Estando presentes todas estas condições, o Juiz deverá deferir a habilitação, sob pena de "violar direito líquido e certo dos legitimados em participar da lide penal e de auxiliar o Ministério Público na obtenção de sentença condenatória" (AVENA, 2014, texto digital). Ademais, a decisão que admitir ou não o assistente é irrecorrível, podendo ser impetrado mandado de segurança para eventual impugnação.

\subsection{Poderes}

As faculdades do assistente de acusação vêm previstas no art. 271, do CPP, que assim preceitua: "Ao assistente será permitido propor meios de prova, requerer perguntas às testemunhas, aditar o libelo e os articulados, participar do debate oral e arrazoar os recursos interpostos pelo Ministério Público, ou por ele próprio (...). Este rol é taxativo, não admitindo analogia, tampouco interpretação extensiva, conforme assevera Avena (2014, texto digital).

Nucci (2014, p. 509) aduz que o assistente de acusação possui o direito de reperguntar e propor perguntas às testemunhas e pessoas ouvidas. Por outro lado, o aditamento ao libelo e o articulado não possuem mais aplicação prática, considerando que este foi substituído pelas alegações finais no processo, as quais são apresentadas individualmente pelo assistente do Ministério Público; enquanto que aquele trata-se de peça não mais existente, sendo cabível somente arrolar outras testemunhas para inquirição em plenário, atentando-se ao máximo legal de cinco testemunhas, segundo dicção do art. 422, do CPP.

Já, os debates orais podem ocorrer em todos os procedimentos (ordinário, sumário e sumaríssimo), além de que o arrazoamento dos recursos poderá ser proposto pelo assistente diretamente nas hipóteses dos artigos 584, § 1으, e 598, do mesmo diploma legal. 


\section{DOS FUNCIONÁRIOS DA JUSTIÇA}

Serventuários e funcionários da justiça são os funcionários públicos, que ocupam os cargos criados por lei, além de receber proventos que são arcados pelo Estado, estando em serviço do Poder Judiciário, segundo elucida Nucci (2014, p. 513). Podem ser os escrivães judiciais, escreventes, oficiais de justiça, auxiliares judiciários, dentre outros.

\subsection{Do Perito}

O Perito é o especialista em determinada área ou matéria, que está incumbido de servir como auxiliar da justiça, colimar em esclarecer e aclarar pontos específicos que se distanciam do conhecimento jurídico do Juiz. Nucci (2014, p. 2013) preceitua que o Perito pode ser oficial, em sendo funcionário do Estado, sendo-lhe dispensado o compromisso, por ter investidura legal; ou ser nomeado pelo Juiz, devendo atuar com compromisso no desempenho da função.

\subsection{Do Intérprete}

O Intérprete é pessoa que detém conhecimento acerca de determinados idiomas estrangeiros, ou, ainda, de linguagens específicas, servindo de figura intermediária entre a pessoa a ser ouvida em juízo e o Juiz e as partes. No desempenho da função, o Intérprete atua como perito, estando compromissado ao exercê-la.

\subsection{Dos impedimentos}

As pessoas que "estiverem cumprindo pena restritiva de direitos (art. 47, I e II, CP), impeditiva do exercício de cargo, função ou atividade pública, bem como de profissão, atividade ou ofício que dependa de habilitação especial, de licença ou autorização do poder público" não poderão exercer a função de perito (NUCCI, 2014, p. 515). O impedimento se dá, também, se o Perito participou de processo como testemunha, ou no caso de ter opinado sobre determinado caso em outro ensejo. Os analfabetos e menores de 21 anos, de acordo com Nucci (2014, p. 515) estão inviabilizados para atuar como peritos.

Ademais, os Peritos deverão atuar com absoluta imparcialidade, considerando que sua função influencia a tomada de decisões pelo Juiz, que formará sua convicção a partir dos elementos probatórios colhidos na instrução, especialmente, no que tange às perícias realizadas, em se tratando de matérias específicas e técnicas que estão longínquas ao âmbito jurídico.

Por fim, assinala-se que o Juiz não poderá atuar como Perito ou Intérprete, visto que não há possibilidade legal autorizando tal prática. Ademais, o magistrado deve manter sua imparcialidade, sendo-lhe vedado 
exprimir qualquer opinião como técnico, ainda que possua amplo conhecimento na matéria específica ou seja conhecedor do idioma estrangeiro.

\section{CONSIDERAÇÕES FINAIS}

Com a realização desta pesquisa, delineou-se identificar, averiguar e minuciar os sujeitos do processo penal, em seus critérios mais relevantes, mormente nas suas funções, direitos e deveres, além de eventuais impedimentos, suspeições, bem como hipóteses ou não de cabimento. Este tema, ressalte-se, outrossim, mostra-se de grande relevância, uma vez que o processo penal somente existirá com a atuação e intervenção dos sujeitos processuais, colimando, acima de tudo, pela observância dos princípios que norteiam a Ação Penal.

Importa repisar, ademais, que cada um dos sujeitos processuais, ora verificados e pormenorizados neste trabalho, exercem funções e atribuições que viabilizam alcançar os fins do processo penal, que consistem em aplicar a lei ao caso concreto, punindo o acusado pelo ato ilícito cometido, através do jus puniendi do Estado. Conferiu-se, outrossim, que é monopólio deste sancionar o criminoso pela conduta desviante, bem como absolvê-lo, caso restar provada a sua inocência.

Inobstante, a partir destas conjunturas e peculiaridades que envolvem o processo crime, verifica-se que este contribui, principalmente, para alcançar a segurança jurídica, tanto para a sociedade, quanto para o Estado, através do restabelecimento da paz social. Logo, por meio da persecução penal, o ente estatal, autônomo e soberano, exerce seu dever e poder de punição, de forma a restaurar a ordem jurídica, imposta pela Constituição Federal, como um dos objetivos do atual Estado Democrático de Direito.

Há que se frisar, ainda, que o advento da constitucionalização remodelou o processo penal brasileiro, incorporando o dever de cumprimento e respeito aos direitos e garantias fundamentais previstas, posto que estes limitaram o jus puniendi estatal, bem como estabeleceram as funções dos sujeitos processuais penais.

Destarte, conclui-se que estes, os sujeitos processuais, devem atuar e desempenhar suas respectivas funções, primando pela efetivação dos direitos e garantias fundamentais, e, acima de tudo, pela busca incessante à justiça.

\section{REFERÊNCIAS}

AVENA, Norberto Cláudio Pâncaro. Processo penal esquematizado. 5. ed. São Paulo: Método, 2013, texto digital.

BRANDÃO, Fernanda Holanda de Vasconcelos. O papel da Defensoria Pública na prestação da assistência jurídica. In: Âmbito Jurídico, Rio Grande, XIV, n. 86, 
mar 2011. Disponível em: <http:/ / www.ambito-juridico.com.br/site/index.php?n_ link=revista_artigos_leitura\&artigo_id=9191>. Acesso em: 20 set. 2016.

BRASIL. Constituição (1988). Constituição da República Federativa do

Brasil. Disponível em: <http://www.planalto.gov.br/ccivil_03/constituicao/ constituicaocompilado.htm>. Acesso em: 20 set. 2016.

BRASIL, Decreto-lei n ${ }^{\circ} 3.689$, de 3 de outubro de 1941. Código de Processo Penal. Disponível em: <http:/ / www.planalto.gov.br/ccivil_03/decreto-lei/ Del3689Compilado.htm>. Acesso em: 20 set. 2016.

BRASIL, Decreto-lei n ${ }^{\circ} 2.848$, de 7 de dezembro de 1940. Código Penal. Disponível em: <http:/ / www.planalto.gov.br/ccivil_03/decreto-lei/Del2848compilado.htm>. Acesso em: 20 set. 2016.

BRASIL, Lei n. ${ }^{8}$ 8.625, de 12 de fevereiro de 1993. Lei Orgânica Nacional do Ministério Público. Disponível em: <http:/ / www.planalto.gov.br/ccivil_03/leis/ L8625.htm>. Acesso em: 20 set. 2016.

CHEMIN, Beatris Francisca. Manual da Univates para trabalhos acadêmicos: planejamento, elaboração e apresentação. 3. ed. Lajeado: UNIVATES, 2015.

JUSTIÇA, Conselho Nacional de. O que vem a ser defensor dativo e defensor constituído? Notícias CNJ, mar 2015. Disponível em: <http:/ / www.cnj.jus.br/ noticias/cnj/78885-noticia-servico>. Acesso em: 20 set. 2016.

LOPES JUNIOR, Aury. Direito processual penal. 10. ed. São Paulo: Saraiva, 2013.

MOREIRA, Rômulo de Andrade. A vítima no processo penal brasileiro. In: JusBrasil, 2015. Disponível em: <http:/ / romulomoreira.jusbrasil.com.br/artigos/199183777/avitima-no-processo-penal-brasileiro>. Acesso em: 20 set. 2016.

NUCCI, Guilherme de Souza. Manual de processo penal e execução penal. 11. ed. Rio de Janeiro: Forense, 2014.

PAES, Janiere Portela Lei. Uma breve análise acerca dos sujeitos no processo penal: conceito e funções. In: Conteúdo Jurídico, jul 2012. Disponível em: <http:/ / www. conteudojuridico.com.br/artigo,uma-breve-analise-acerca-dos-sujeitos-no-processopenal-conceitos-e-funcoes,37961.html>. Acesso em: 20 set. 2016.

PETEK, João Pedro. O novo papel da vítima no processo penal e a assistência à acusação. In: PUC/RS, nov 2010. Disponível em: <http:/ / www3.pucrs.br/pucrs / files/uni/poa/direito/graduacao/tcc/tcc2/trabalhos2010_2/joao_petek.pdf >. Acesso em: 20 set. 2016.

PUPO, Matheus Silveira. A autodefesa. In: JusBrasil, 2011. Disponível em: <http:/ / matheuspupo.jusbrasil.com.br/artigos/121938055/a-autodefesa>. Acesso em: 20 set. 2016. 
RODAS, Sérgio. Estado é obrigado a pagar honorários advocatícios de defensor dativo. In: Consultor Jurídico, jul 2015. Disponível em: <http:/ / www.conjur.com. br/2015-jul-14/estado-pagar-honorarios-advocaticios-defensor-dativo >. Acesso em: 20 set. 2016.

SANTOS, Suzycleide de Almeida. Os sujeitos do processo penal. In: Viajus, jul 2010. Disponível em: <http:/ / www.viajus.com.br/viajus.php?pagina=artigos\&id=2998>. Acesso em: 20 set. 2016.

SOUZA JUNIOR, Eldio Martins de. A atuação da Defensoria Pública, frente os princípios constitucionais da ampla defesa no processo penal. In: DireitoNet, dez 2006. Disponível em: <http:/ / www.direitonet.com.br/artigos/exibir/3040/ADefensoria-Publica>. Acesso em: 20 set. 2016.

TORRES, Fernando. Sujeitos processuais penais. In: JusBrasil, 2015. Disponível em: <http:/ / fernandotorres698.jusbrasil.com.br/artigos/177851272/sujeitos-processuaispenais>. Acesso em: 20 set. 2016.

VALE, Ionilton Pereira do. Os tipos de defesa no processo penal: A defesa técnica e a autodefesa. In: JusBrasil, 2014. Disponível em: <http:/ /ioniltonpereira.jusbrasil.com. br/artigos/155145312/os-tipos-de-defesa-no-processo-penal-a-defesa-tecnica-e-aautodefesa>. Acesso em: 20 set. 2016. 